DOI: $10.2478 /$ ausfm-2014-0021

\title{
The New Realistic Trend in Contemporary World Cinema: Ramin Bahrani's Chop Shop as a Case Study ${ }^{1}$
}

\author{
Fernando Canet \\ Polytechnic University of Valencia (Spain) \\ E-mail: fercacen@upv.es
}

\begin{abstract}
In the last two decades there has been an international resurgence of realistic films, i.e., films directed by filmmakers who believe in the ontological power of reality and, at the same time, in the capacity of the medium's expressive scope for building a story without undermining the viewer's impression of reality. On the one hand, this new movement is a rehabilitation of the cinematic Realism that throughout the history of film has touted cinema as an open window to the real world, a view particularly exemplified by Italian Neo-Realism. On the other hand, this new trend has given new life to the Realist film theories championed mainly by André Bazin and Siegfried Kracauer. Bazin defines the Realist style as "all narratives means tending to bring an added measure of reality to the screen" (1971, 27). In the article titled Neo-Neo Realism (2009), A. O. Scott discusses a number of filmmakers whom he categorizes within the new Realist trend in contemporary American independent cinema. Among these is Ramin Bahrani, director of the film Chop Shop (2007). Bahrani is a USborn filmmaker of Iranian origin, based in New York. Abbas Kiarostami is one of his main points of reference. Kiarostami, as Scott notes, "refined the old Neorealist spirit through the 1990s and into the next decade." Bahrani himself acknowledges this influence with his desire to make "an Iranianstyle movie here in New York.”
\end{abstract}

Keywords: Ramon Bahrani’s Chop Shop, realism, contemporary American independent cinema.

1 The research for this article was enabled with the support of the Research Project "Study and analysis for development of Research Network on Film Studies through Web 2.0 platforms," financed by the National R+D+i Plan of the Spanish Ministry of Economy and Competitivity (code HAR2010-18648). 


\section{Introduction}

"What is more real in our universe than a man's life, and how can we hope to preserve it better than in a realistic film?" These words are Albert Camus's, and with this quote Roy Armes opens the first part of his book titled Patterns of Realism, which he wrote about Italian Neo-Realism in 1971. With his rhetorical question, Camus identifies two of the main bastions upholding any Realist project: on the one hand, the object of study is reality itself, which is the reference point throughout the creative process; and on the other, reality is constructed according to certain expressive codes that define a particular style, which is known in the different forms of artistic expression - painting, literature, and film - as the Realist style. This is all with the intention of representing as accurately as possible, returning to the words of Camus, the reality that has aroused the interest of an author who, for whatever reason, has been drawn to it.

Nevertheless, although it may be among the author's intentions to capture reality as honestly as possible, that representation can never be an exact reproduction of reality, as the nature of representation in itself prevents this. Thus, André Bazin $(1971,26)$ speaks of the "illusion of reality;" however, that illusion, according to the predicates of the French critic himself, should be as close as possible to its referent, of course within the "limits of the logical demands of cinematographic narrative and of the current limits of technique," since, as Colin MacCabe notes (1976, 9), "for Bazin, as for almost all Realist theorists (among others, Lapsley and Westlakem 1988, Bill Nichols 1991, and Brian Winston 1995), what is in question is not just a rendering of reality but the rendering of a reality made more real by the use of aesthetic device." Thus, according to these theorists, Realism is a set of conventions and norms for representing reality transparently, thereby achieving what Stephen Prince $(1996,31)$ calls the "reality effect." This set of codes is known as the Realist style.

It is an undeniable fact that over the last two decades the international film scene has seen a significant number of independent films with an authorial tone that have taken the real world as their point of reference, approaching that real world through the application of a Realist style. These films have had a notable impact both at major festivals and with international critics. An example of the latter is the article written by A.O. Scott (2009) of The New York Times titled Neo-Neo Realism. In this article, Scott, one of the most renowned critics in New York City, echoing the expression used to define Italian cinema of the post-war era, describes the new Realist trend in contemporary American independent 
cinema as Neo-Neo Realism. ${ }^{2}$ This new movement began in the early 1990 s and although it would have a worldwide impact it developed mainly as a national trend in certain countries. Perhaps the one that has had the greatest impact has been the Iranian movement, with internationally acclaimed directors like Abbas Kiarostami, Mohsen Makhmalbaf, and Jafar Panahi. As will be discussed below, Iranian films have been among the main sources of inspiration for the director of the film examined in this article.

As noted above, the main point of reference for this type of film is the work of Italian film-makers such as Roberto Rosellini, Luchino Visconti, and Vittorio de Sica, who, after the end of World War II, "by taking their cameras out into the streets and forgetting the dead rules of conventional film-making, come face to face with reality again" (Armes 1971, 20). Thus, the dramas were found on the streets of a Europe destroyed after the war; all that was needed was the ability to observe this mutilated reality to find the seeds of possible stories that told of the terrible consequences for a society torn apart by military conflict. It must be said - and herein lies the main ongoing influence of Italian Neo-Realism - these directors knew how to approach reality the right way. They did this through a Realist style that could both reproduce and represent reality on the screen in an authentic manner, avoiding the artificiality that characterised studio film prior to World War II.

However, "the creative treatment of actuality," to appropriate the famous expression attributed to John Grierson, can be traced back to the early 1920s, to two film-makers for whom reality was also the benchmark: André Antoine and Robert J. Flaherty. Nonetheless, unlike their predecessors, the Lumière Brothers, rather than merely reproducing reality, these film-makers construct it creatively, taking storytelling strategies from the fictional narrative style of popular cinema, which was already dominant by that time. La terre (Earth, André Antoine, 1921) is the result of years of filming in the Beauce region south-west of Paris. In order to avoid the artificiality of stories acted out in the studio, Antoine travelled to the Beauce region to adapt the Émile Zola novel of the same name, set in this French region in the late 19th century (the novel was published in 1887). Thus, Antoine's work (both his films and the plays with which he began his career) was influenced by the Naturalist and Realist postulates of 19th century literature represented particularly by Zola and fellow French writer Honoré de Balzac (see Erich Auerbach 1946).

2 Scott's critique focuses mainly on productions released in 2008 and 2009, made, among others, by So Yong Kim, Ramin Bahrani, Lance Hammer, Anna Boden, Ryan Fleck, and Kelly Riechardt. 
As Quintana $(2003,69)$ points out, Antoine's adaptation of La terre establishes one of the basic elements of cinematic realism: "the difficulty of finding a balance between film reproduction and the rhetorical processes of reality construction that are characteristics of fiction." Indeed, in La terre this balance was not fully achieved. Both the artificiality of an excessively forced interpretation, which undermines the authenticity of the story narrated (the actors were not real peasants but actors from the Comédie Française and the Odéon Theatre in Paris), and the excessive dependence on dramatic structure detract from the more realistic scenes where rural life in this region of France takes the central role. As a result, "the most interesting moments in La terre occur when the drama takes second place and the dominance of the landscape reduces the bodies of the actors to the status of mere figurative extras" (Quintana 2003, 70).

On the other hand, this adulteration of reality through excessive dramatization of the narration is less of a problem in the film shot in this same period by Robert J. Flaherty. In his case, referential reality is much more distant and exotic than in the case of Antoine. The Barren Lands and the Eskimos who inhabit it were the subject of the Nanook of the North (1922), Flaherty's first film. As Robert Sherwood $(1979,16)$ notes, "Mr. Flaherty had to spend years with the Eskimos so that he could learn to understand. Otherwise, he could not have made a faithful reflection of their emotions, their philosophy, and their endless privations." An Eskimo, Nanook, was the one selected to become the character. Thus, unlike in Antoine's film, a real person is the protagonist of the plot constructed to represent reality. Through tracking Nanook's life, Flaherty vested the movie with temporal continuity as well as dramatic structure. But unlike Antoine, Flaherty manages to achieve a perfect balance between the reproduction of reality and its dramatisation, thereby successfully conveying the illusion to spectators that everything shown on the screen is real.

To differing degrees, these two films and the works of Italian Neo-Realism can be considered examples of what Bazin defined as the Realist style, which he describes as "all narrative means tending to bring an added measure of reality to the screen" $(1971,27)$. These films are also points of reference for the new resurgence of the Realist style in contemporary film, a movement which in turn has revived an interest among film theorists in cinematographic Realism. Thus, in recent years a significant number of essays have been published on this question, which, after being disparaged by the dominant theoretical movements of the 1960s and 1970s, has now regained a certain prominence in film studies. Indeed, in the past few years, and very especially in 2011, the Realist film theories championed 
in the 1940s by André Bazin and Siegfried Kracauer are resurfacing in the work of Richard Rushton (2011), Dudley Andrew (2011), Bert Cardullo (2011), and Lúcia Nagib (2011), among others. Contemporary Realism was even the topic of the special autumn issue of Cinephile: The University of British Columbia's Film Journal, edited by Shaun Inouye.

In short, the purpose of this article is to examine the codes that define the Realist style today, and how through the application of this style filmmakers can ensure, on the one hand, a perfect balance between the reproduction and construction of reality and, on the other, that this very dramatisation, developed with the purpose of eliciting an emotional response from the spectator, does not undermine the authenticity of reality on the screen, but, on the contrary, keeps the illusion or effect of that reality unadulterated, so that spectators experience the stories told as true stories. In order to assess the relevance of the Realist style in contemporary film, I have analysed a contemporary film by a director who, according to Scott, forms part of the new Realist trend in contemporary American independent cinema. The director is Ramin Bahrani and the film in question is Chop Shop (2007).

Bahrani is a US-born filmmaker of Iranian origin. He has tried, despite the considerable distance involved, to keep in touch with his cultural roots through contact with the well-known Iranian filmmaker Abbas Kiarostami, whom we could define as his film-making mentor and who, as Scott (2009) notes, "refined the old Neorealist spirit through the 1990s and into the next decade." Bahrani himself acknowledges this influence through his desire to make "an Iranian-style movie here in New York." ${ }^{3}$

\section{Real Life as Subject}

As MacCabe $(1976,9)$ notes, "by the criteria of one of the great Realist critics, André Bazin, for a film to be realistic, it must locate its characters and action in a determinate social and historical setting." The specific reality dealt with in this film is relatively unknown; the Willets Point neighbourhood in Queens, although paradoxically it is located in the city most often portrayed in the history of film, New York City. Willets Point is one of the most neglected areas of Queens, popularly known as the Iron Triangle for its chop shops. "Chop Shop" in the local slang means an undercover workshop where cars are broken up for spare parts to be sold on the black market, thus making the whole area an authentic junkyard, a particular diegetic universe, full of dismantled cars and unpaved dirty streets

3 This quote is taken from an interview with Scott, and is quoted in Scott's article. 
in which the puddles only dry up during the hot days of summer. [Figs. 1-2.] The film lifts the curtain by placing this real location in context. The director chooses a setting outside the neighbourhood to focus on the distant skyscrapers of Manhattan, as if letting the audience know from the beginning that this is, although it does not seem like, a story set in New York City. [Fig. 3.]

Later in the movie, Bahrani also uses another First World symbol, the nearby City Field (the new stadium for the New York Mets baseball team), as a contrast to the Third World-esque Willets Point. [Figs. 4-5.] For Bahrani it was paradoxical to observe how quickly you could migrate from a place of despair to another where you could read on a giant billboard "Make Dreams Happen". Bahrani confesses he was curious to know "what dreams can happen in this place?," or in other words, how can the American Dream be so close yet so far away for those who live in Willets Point? Indeed, in this city one is constantly aware of the geographical proximity of such socially and culturally distant worlds.

It was, in fact, precisely this gray world of poverty that inspired the director to make the film. Thus, reality was the inspiration for the story. As Alain Cavalier points out, movies are born of an encounter. Bahrani's cinematographer, Michael Simmonds, came to Willets Point looking for a spare part for his car, immediately fell in love with the place and told Bahrani about it. After visiting the neighbourhood in the winter of 2004, Bahrani, whose first reaction was: "My God, this place is the world, the world in 20 blocks," motivated by that inner drive to understand a subject, whether it is far away or just around the corner, decided to make what would be his second feature film, Chop Shop, a project that came to fruition three years later.

As Jean Rouch claimed in his first short film, Initiation à la danse des posseder (Initiation into Possession Dance, 1949), "an essential condition for portraying reality is to be a part of it." Of course, Flaherty had already done this before him. It took him three years to shoot his first film, Nanook of the North (1922). Thus, as Rouch himself suggests (1962), "Flaherty believed that, in order to film some men belonging to a foreign culture, it was necessary first to know them." Likewise, as Viestenz (2009, 544-545) observes, the ethos of "first living, then filming" is posited not only by Flaherty but also by Christian Metz (1999, 356-359) in his essay Aural Objects: "In order for me to have tried to dismantle the 'objects' which so strike the native [...] it was necessary that I be that native myself." Bahrani himself admits in his film's pressbook that he spent a year trying to become part of the world of the Latino children who spent their time in the workshops or roaming the streets of Willets Point. As Roy Armes points out $(1971,187)$, "the 
basic material is experienced at first hand by the film-maker before the film is elaborated. De Sica studied the shoeshine boys before making Sciuscià and Rossellini went to Berlin before beginning work on Germania anno zero."

Thus, the observation of reality allowed him to pick and choose what interested him most: the kids. Bahrani himself admits in his film's pressbook: "I became increasingly interested in the lives of these young boys who worked and lived amidst grown men, in this very tough location. I wanted to know who they were, what kind of dreams they had, and how they managed the challenges and decisions that most of us as adults never have to face." Thus, the main character in Chop Shop is Ale (Alejandro Polanco), a child growing up on the street, who has to struggle with the hostile environment. Even though Ale is Latino, speaks Spanish, and is not a professional actor, he doesn't really belong to the group described above. He was born and grew up in Manhattan's Lower East Side. However, Bahrani knew how to solve this problem by sending Ale to soak up the local atmosphere. He thus spent six months in Rob Sowulski's shop - the real owner, who also plays himself in the film - before shooting started, learning firsthand the skills he would need rather than merely performing them in front of the camera. Ale points out in the film's pressbook: "Every day I would get like $\$ 30$, I learned how to sand down cars, paint cars, and how to fix dents. I even learned how to drive! It was really hard but a lot of fun." He thus managed to become part of the neighbourhood, making friends and getting respect from adults to the point that, as the director says, "People in the Iron Triangle thought we were making a documentary about Ale, a boy who worked there, because they'd really seen him working there for so long." [Fig. 6.]

We can find the narrative of the child growing up on the street who has to struggle with a hostile environment in Vittorio de Sica's Shoeshine (Sciuscià, 1946), Roberto Rossellini's Germany Year Zero (Germania anno zero, 1948), and Luis Buñuel's Los Olvidados (The Forgotten Ones, 1950). As Bahrani himself recognizes, "if [Luis Bunuel's] Los Olvidados were to be made today in America, it would be made here," referring to Willets Point. Moreover, Ale reminds us of Alexandre Napoleon Ulysses Latour in Flaherty's Louisiana Story (1948), or, more recently, the leading children in contemporary Iranian Realism, for instance, Ahmed in Abbas Kiarostami's Where is the Friend's Home? (1987), Mina in Jafar Panahi's The Mirror (1997), Massoumeh and Zahra Naderi in Samira Makhmalbaf's The Apple (1998), to name a few. All of these children are real people from the reality that has been selected as subject, who are picked out to become the protagonists of the plots developed in the film. As Bazin notes (1971, 
24), "The non-professionals are naturally chosen for their suitability for the part, either because they fit physically or because there is some parallel between the role and their lives." Bazin's words can be applied to anybody, whether an adult or a child. In the specific case of children, given their innocence and lower level of awareness of the mechanism of filmmaking, their performance may prove much more spontaneous and therefore more genuine. It is therefore no surprise that a film genre that aims for naturalness in its representation should have a preference for stories in which children are the protagonists.

Another hallmark that defines the Realist style is the focus on everyday routine. As Bill Nichols notes $(1991,165)$, "Realism builds upon a presentation of things as they appear to the eye and the ear in everyday life." Thus, in Chop Shop, through the point of view of Ale, the audience can see how the characters break up, sand, polish and paint cars, change tyres or lure customers to their shops and also show people in their time off, having fun playing dice or enjoying barbecues, while the ever-present Latin music can be heard blaring out in the background. As Bordwell points out (2009), Chop Shop features "a greater sense of 'dailiness.”'

\section{Combining Threads of Routine Structures with Dramatic Structure}

The reality in which these children live is not easy; on the contrary, it is full of travails and challenges that they have to face. Such conflictive situations are the perfect pretext for unfolding dramatic structures in the film. Thus, in Realist films there is a place for both dramatic structures and the threads of routine structures. Indeed, part of the success of this type of film lies in the ability to combine typically everyday activities with dramatic episodes. This balance is achieved by alternating moments in the film in which routines occupy the foreground with moments in which such routines move into the background. Generally, everyday activities play a more central role at the beginning of the film, where the presentation of the context and the activities carried out in that context are the focus of attention. As the story develops, these activities lose their importance, giving way to dramatic episodes. Nonetheless, scenes of everyday activities not only serve the purpose of presenting the reality in which the action occurs but also of planting information that will be of relevance later on in the narration when more dramatic situations unfold. As Bordwell notes (2009), "most of the routines establish a backdrop against which moments of change and conflict will stand out." To illustrate this point, Bordwell makes reference to the scene in which Ale and his buddy Carlos 
discover that Ale's sister, Isamar, "has become one of the hookers who service men in the cab of a tractor-trailer [...]. Bahrani's script motivates their discovery by explaining that they habitually spy on the truck assignations [...]. In two later scenes, the truck-stop becomes an arena for conflict."

This situation proves very moving for Ale. As Greg G. Smith notes (2003, 102), "dense configurations of emotion cues to mark scenes in which characters make important recognitions." This recognition situation also marks a shift in the character's hardships. Although Ale's situation is not easy, he has a close friend, gets a job, gets a home, and, ultimately, gets his sister to live with him. Things are going well (positive value) and, moreover, he has a goal to improve his situation; as many cognitive film theorists point out, ${ }^{4}$ goal-driven plotting is central to unfolding an emotional film structure. He wants a better life for Isamar and for himself, and so he works hard to save money to buy a van, which will be repaired to convert it into a push cart to sell food on the street. From this emotional turning-point to the end of the film, the character's situation goes from bad to worse. As is very common in classical narrative, the crisis unfolds in the climax, the peak dramatic moment, when Ale is faced with the most emotionally charged situation.

Ale ultimately decides to face the situation involving Isamar. Having so decided, he heads off again to the truck stop with the intention of putting a stop to his sister's activity. The moment is filled with emotion, mainly due to the fact that what is at stake for Ale is of vital importance to him, because, as Ed S. Tan notes $(2009,44)$ "without concerns, there can be no emotion; conversely, emotion signifies that some concern of the individual has been affected." At the same time, the scene seems real. And this is due mainly to Bahrani's style of direction. With the purpose of eliciting an authentic reaction from Ale, Bahrani took advantage of an incident that the youth had experienced when he was only nine years old. At that age, he witnessed a murder that seriously disturbed him. Bahrani thus took a fake gun and gave it to the man who was enjoying Isamar's services, telling him to put it to Isamar's head in order to add an element of terror to the situation. The strategy achieved its aim, striking an emotional chord in Ale. The anger provoked by his memory resulted in an aggressive response to the man with the fake gun. As Bahrani (Richard Porton 2008, 46) himself wonders: "is Ale's reaction acting or is it a documentary reaction to an event? It doesn't matter. There's only one question that matters: does it work and is it a good story?"

4 On character's goals, see Greg M. Smith, Film Structure and the Emotion System, (Cambridge University Press, 2003); and Carl R. Plantinga, Moving Viewers: American Film and the Spectator's Experience (University of California Press, 2009) 
After this intense moment, Bahrani allows time to go by for the situation to cool down. Time for both Ale and Isamar to reflect about their situation; time to allow not only the external actions but also the internal action of the characters to unfold. Time for what Robert Bresson calls (1997) "sculpting the invisible winds through the motion of waves;" in other words, to make visible what is invisible, in this case the emotions of the characters. Thus, after the stormy night, the new day brings calm. With the dawn, a hopeful situation arises. A moment charged with emotion for the characters has passed, and reconciliation is extremely important to both. As Nichols points out $(1991,155)$, "emotional realism selects aspects of a scene in accordance with their emotional importance to characters." Just a few seconds are necessary to provoke this emotive moment, for three main reasons: firstly, as already stated, what is at stake for the characters is very important; secondly, after a series of negative situations, the mood of the narrative needs to be broken with a positive one (that is, after conflicts, a moment of pleasure is experienced at the end, even if the situation staged is as minimal as the return of a smile to the characters' faces and pigeons taking flight) [Fig. 11]; and thirdly, Ale's goal is partially achieved. As Bordwell points out (2009), "so we have an open, somewhat ambivalent ending - another convention of realist storytelling and modern cinema (especially after Neorealism). Life goes on, as we, and many movies, often say."

\section{Searching for Naturalness and Authenticity}

The prior cohabitation with the reality to be filmed, as noted earlier, and the subsequent rehearsals held in the same locations not only serve to start shaping the dialogues and actions, but also to begin structuring the plot to be acted out by the three children in this reality chosen as the context for the plot. Thus, in addition to allowing the children to begin assuming their roles in the story and establishing the relationships between them, the rehearsals helped them to begin adapting to the environment so that to some extent they begin to feel part of the reality of Willets Point. At the same time, the rehearsals were performed on camera, thereby mitigating the dreaded "camera effect." This is a key point, especially in cases where the characters are being performed by non-professionals. Thus, in Chop Shop the rehearsals also served to accustom the three children to the film equipment so as to reduce their consciousness of its presence during shooting. One of the essential purposes of all this preliminary work is to achieve the highest degree of naturalness and authenticity possible in the final product. 
So that these two qualities would not be lost during filming, Bahrani and his cinematographer decided that they should apply documentary techniques. Thus, the actions in every scene had to be kept as simple as possible. As Bahrani expressed it: "In almost all of our conversations about how to shoot it, we would say, 'What's the simplest way?' Almost every scene is one shot, with sometimes quite complicated mise-en-scene, even though it may appear simple." Bahrani thus follows Bazin's theory $(1971,65)$ on the importance of respecting "the actual duration of the event." In this context, the words of film-maker Trinh T. MinhHa $(2007-2008,228)$ become especially relevant: "Real time is considered more 'credible' than film time, so that the long take [...] and to edit a minimum or not to edit [...] is considered the most appropriate [way] to avoid distortions in the structure of material." Another strategy that brings the film closer to reality is to allow the actors to improvise when shooting a scene. Bahrani would avoid saying "action" or "cut," in order to capture spontaneous footage of both the actors and the location. Sometimes even the crew could not distinguish between the script and the improvisations. Moreover, he often aims for spontaneity by changing the situation without telling the actors. As Vertov believes, the only way to make the sequence more real is precisely through spontaneity. Nonetheless, spontaneity was not the only strategy that Bahrani used during shooting; control was also extremely important. As Scott points out (2009), "transparency, immediacy and a sense of immersion in life are not the automatic results of turning on a camera but rather effects achieved through the painstaking application of craft." Thus, the camera movements, composition, and details into the frame were also adjusted and controlled by director and crew.

Therefore, another of the hallmarks of the Realist style is the tension between scripted situations, which are acted out by the characters, and unscripted situations that arise from the spontaneity of the moment. This is particularly true in unstaged public scenes where the only controlled aspect is the action of the main character. This happens in the scenes in which Ale and his friend Carlos sell candy on the subway or when Ale is waiting for his sister on the platform. In the first case, a small crew with a hand-held camera is the only way to shoot the scene without altering the environment in which the action unfolds. [Fig. 7.] In the second case, the effect is achieved by using lenses in a selective approach that keeps Ale in focus at all times, even though he often disappears into the crowd waiting for the train. [Fig. 8.] Both scenes are especially reminiscent of the Neorealist scenes. As Roy Armes $(1971,191)$ notes, "streets, crowds and railway-stations, the countryside and the sea all provide marvelously expressive 
backgrounds for the film to use and the sense of life going on beyond the limits of the frame is one of the great qualities of this new cinema." Bazin, (2004, 313) referring to such scenes, said: "The subtlety and flexibility of the camera movements in these tight and crowded spaces, and the natural behavior of all persons in frame, are the main reasons that make these scenes the highlights of Italian cinema."

\section{Conclusion}

Chop Shop is a film that exemplifies the rebirth in the last two decades of a Realist trend in contemporary world cinema based on a belief in the ontological power of reality. This is the seed of the story, which is nurtured and grown through the contact that its author has with this reality throughout the creative process. Moreover, this reality is the real background in which the plot unfolds. And this reality can also become the foreground of the film, and can even change the plot during shooting. Thus, the tension between reality and fiction is one of the key aspects of Realism. Indeed, the question of how to integrate fiction into the real world without undermining the viewer's impression of reality is one of the main concerns of cinematic Realism, as the foremost purpose of this type of cinema is to make the film look real.

To achieve this, film-makers apply the Realist style, a set of conventions and norms which tell the story in the context of the real world using devices that are closer historically to the documentary genre and which allow the reproduction of reality so that what is filmed doesn't seem staged, but has the appearance of life unfolding before the camera. I refer here to the documentary's impulse for attaining that utopia of authenticity: making the film look real. On the other hand, this style also involves the dramatization of reality using devices from fiction to achieve character engagement (on this topic see the work of cognitive film theorists, especially Murray Smith [2004], Noël Carroll [2007], and Amy Coplan's works [2009]), which is central to the spectator's emotional response to a film. The proper balance between these two devices is crucial to the success of the Realist approach to reality, since the more realistic the effect achieved in the film, the truer the emotions that surface on the screen. 


\section{References}

Andrew, Dudley, ed. 2011. Opening Bazin: Postwar Film Theory and its Afterlife. Oxford: Oxford University Press.

Armes, Roy. 1971. Patterns of Realism. A study of Italian Neo-Realist Cinema. New York: A.S. Barmes.

Auerbach, Erich. 1946. Mimesis: the representation of reality in western literature. Bern: Francke.

Bazin, André. 1971. What is cinema? Volume II. University of California Press. Bazin, André. 2004. ¿Qué es el cine? [What is Cinema?]. Madrid: Rialp.

Bordwell, David. 2009. Getting real. Observations on Film Art. http://www. davidbordwell.net/blog/2009/05/03/getting-real/ Last accessed at 27. 07. 2013.

Bresson, Robert. 1997. Notes on the Cinematographer. Green Integer.

Cardullo, Bert, ed. 2011. André Bazin and Italian Neorealism. New York: Continuum.

Carroll, Noël. 2007. The philosophy of motion pictures. Oxford: Blackwell.

Coplan, Amy. 2004. Empathic Engagement with Narrative Fictions. Journal of Aesthetics and Art Criticism vol. 62: 141-52.

Coplan, Amy. 2006. Catching Characters' Emotions. Film Studies: An International Review vol. 8: 26-28.

Coplan, Amy. 2009. Empathy and Character Engagement. In The Routledge Companion to Philosophy and Film, eds. Paisley Livingstone and Carl Plantinga, 97-110. New York: Routledge.

Elsaesser, Thomas and Malte Hagener. 2010. Film Theory an introduction through the senses. New York and London: Routledge.

Inouye, Shaun. 2011. Contemporary Realism. Cinephile: The University of British Columbia's Film Journal vol. 7 no. 2 (Fall).

Lapsley, Robert and Michael Westlakem. 1988. Film Theory: An Introduction. Manchester: Manchester University Press.

MacCabe, Colin. 1976. Theory and Film: Principles of Realism and Pleasure. Screen vol. 17 no 3: 7-28.

Metz, C. 1999. Aural Objects. In Film Theory and Criticism, eds. Leo Braudy and Marshall Cohen, 356-59. Oxford: Oxford University Press.

Nagib, Lúcia. 2011. World Cinema and the Ethics of Realism. London: Continuum. Nichols, Bill. 1991. Representing Reality: Issues and Concepts in Documentary. Indiana Indiana University Press. 
Plantinga, Carl. 2009. Moving Viewers: American Film and the Spectator's Experience. University of California Press.

Porton, Richard. 2008. A Sense of Place. An Interview with Ramin Bahrani. Cineaste vol. 33 no. 3 (Summer): 44-48.

Prince, Stephen. 1996. True Lies: Perceptual Realism, Digital Images, and Film Theory. Film quarterly vol. 49 no. 3: 27-37.

Quintana, Ángel. 2003. Fábulas de lo visible. El cine como creador de realidades [Fables of the visible: film as a creator of realities]. Barcelona: Acantilado.

Rouch, Jean. 1962. Le cinéma de l'avenir? [The Cinema of the Future?] Domain Cinéma, vol. 1: 44-52.

Rushton, Richard. 2011. The reality of film: Theories of Filmic Reality. Manchester: Manchester University Press.

Scott, A. O. 2009. Neo-Neo Realism. The New York Times 17 March. http://www. nytimes.com $/ 2009 / 03 / 22 /$ magazine $/ 22$ neorealism-t.html?pagewanted=all, $r=0$. Last accessed at 27. 07. 2013.

Sherwood, Robert. 1979. Robert Flaherty's Nanook of the North. In The Documentary Tradition, ed. Lewis Jacobs, 15-19. Toronto: George J. McLeod Limited.

Smith, Greg G. 2003. Film Structure and the Emotion System. Cambridge: Cambridge University Press.

Smith, Murray. 2004. Engaging Characters: Fiction, Emotion, and the Cinema. New York: Oxford University Press.

Tan, Ed S. 2009. Emotion and the structure of narrative film: film as an emotion machine. New York: Routledge

Trinh T. Minh-Ha. 2007-2008. The Totalizing Quest of Meaning. Archivos de la Filmoteca vol. 2 no. 57-58 (October-February): 223-247.

Viestenz, William. 2009. Cinematic Ethics within the Picnoleptic Moment in José Luis Guerín's En construcción. The Bulletin of Hispanic Studies vol. 86 no. 4: 537-553.

Winston, Brian. 1995. Claiming the real: The Griersonian documentary and its legitimations. London: British Film Institute. 


\section{List of Figures}

Figures 1-8. Screenshots from Ramin Bahrani’s Chop Shop (2007)
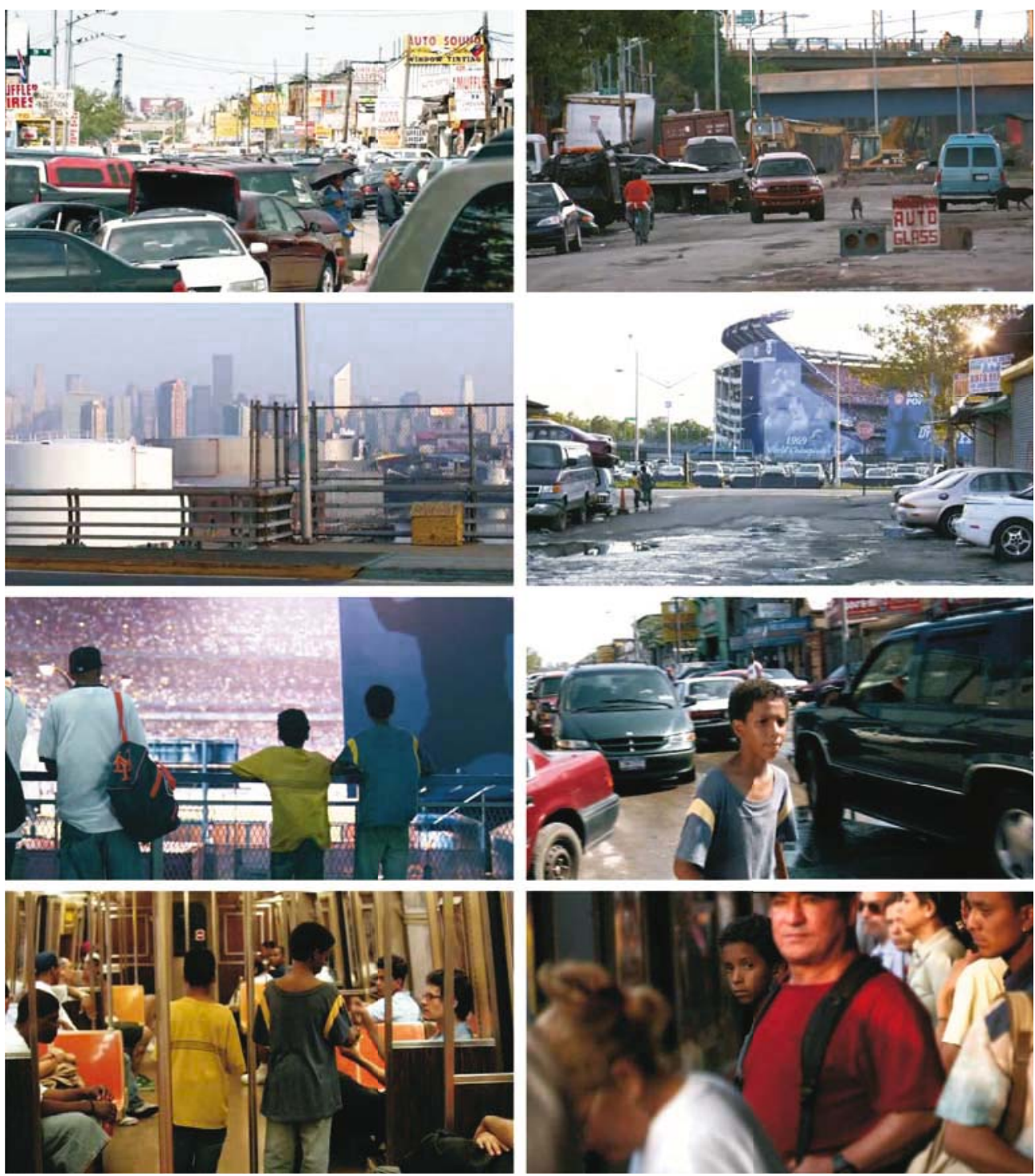